\title{
Left ventricular ejection power in coronary artery disease during atrial pacing
}

\author{
KLAUS HAGEMANN, JUERGEN MEYER, RAINER v. ESSEN, \\ WINFRIED KREBS, AND SVEN EFFERT
}

From the Department of Internal Medicine I, Rheinisch-Westfaelische Technische Hochschule, Aachen, Federal Republic of Germany

SUMMARY Peak and mean left ventricular ejection power were measured during atrial pacing in 6 normal subjects (group I), 6 patients with coronary artery disease without myocardial infarction (group IIa), and 10 patients with coronary artery disease after myocardial infarction (group IIb). Pacing rates were 80 and $120 / \mathrm{min}$. Power was determined by computer analysis of pressure, volume, and time. Data were normalised by end-diastolic volume and left ventricular muscle mass.

Peak left ventricular ejection power normalised by end-diastolic volume in normal subjects increased from 53.4 to $68.2 \mathrm{~mW} / \mathrm{ml}(+28 \%, P<0.01)$. No change was seen in group IIa and IIb. Peak and mean left ventricular ejection power normalised by end-diastolic volume values at a pacing rate of $120 \mathrm{~min}$ were significantly lower in group IIa and IIb than in normal subjects. Mean muscle mass in normal subjects was $179 \mathrm{~g}$ and in group IIa $216 \mathrm{~g}(\mathrm{P}<0.05)$. Peak power normalised by muscle mass in normal subjects tended to increase at $120 / \mathrm{min}$ whereas in group IIa it declined by 26 per cent (P $<0.001$ ).

These data indicate that the energy output of the left ventricle at rest may be the same in patients with significant coronary artery disease as in normal subjects. Increasing the heart rate from 80 to $120 / \mathrm{min}$ in a normal myocardium augments power but in coronary artery disease it remains static or falls.

Left ventricular dynamics can be described in terms of pressure, volume, and time. Pressure analysis according to the principles of the forcevelocity-length relation has been performed by numerous investigators (Brutsaert and Sonnenblick, 1973; Sonnenblick and Strobeck, 1977). This method has answered many questions about the contractile behaviour of the myocardium in health and disease. Nevertheless it is based upon theoretical assumptions derived from isolated muscle preparations, and the validity of data from the intact heart is limited. Furthermore, pressure analysis gives no direct information about the function of the ventricle as a pump. It has been shown in studies on ventricular volume that the ejection fraction and the velocity of circumferential fibre shortening have value in the detection of myocardial abnormality (Sonnenblick and Strobeck, 1977). However, these indices do not describe pump function adequately, whereas left ventricular power during ejection combines the time-dependent

Received for publication 17 April 1978 changes in ventricular pressure and volume, and in animals has been shown to be useful as an index of cardiac performance under various haemodynamic conditions (Stein and Sabbah, 1976a, b).

This study was undertaken to determine left ventricular power in normal subjects and in patients with coronary artery disease both at rest and under stress, using a computer programme for simultaneous analysis of pressure, volume, and time developed by the group.

\section{Subjects and methods}

\section{PATIENTS}

The study was performed in 22 patients referred to our department for diagnostic cardiac catheterisation. Twenty-one were male and one (case 5) female. Six of the subjects were considered normal by noninvasive techniques, haemodynamic measurements, and coronary arteriography (group I, mean age $38 \pm 12$ years). These were studied because of chest pain of undetermined origin. Sixteen patients had coronary artery disease as shown by coronary 
arteriography (group II, mean age $49 \pm 6$ years) and were potential candidates for coronary artery surgery. Six of these patients had no history of myocardial infarction (group IIa, mean age $46 \pm 7$ years); in the remaining 10 , previous myocardial infarction had been clearly documented by electrocardiography and enzyme studies (group IIb, mean age $50 \pm 5$ years). Sinus rhythm with normal atrioventricular conduction was present in all subjects. Patients with significant hypertension, mitral valve regurgitation, or major left ventricular wall motion abnormalities were exluded from the study. There was no statistical difference in body surface area between the groups (mean 1.83 \pm $0 \cdot 11 \mathrm{~m}^{2}$ ).

\section{CARDIAC CATHETERISATION TECHNIQUES}

Left and right heart catheterisation was performed in the fasting and recumbent state without premedication. Catheters were introduced under local anaesthesia using the Seldinger technique via the femoral vessels. Left ventricular and aortic pressures were measured simultaneously by catheter tip manometer ${ }^{1}$ and a fluid filled catheter (multi purpose type ${ }^{2}$ ), respectively. In some instances a single catheter with two manometers was used. ${ }^{1}$ The zero reference pressure was set at $5 \mathrm{~cm}$ below midchest level. Left ventricular angiography was performed by injection of 60 to $70 \mathrm{ml}$ of 70 per cent Na-meglumine-iotalamate into the right atrium or pulmonary artery using a pigtail catheter ${ }^{2}$ With this technique premature ventricular contractions were completely avoided, and left ventricular volume remained unchanged throughout the period during which it was visible. This method has been described elsewhere in detail (Hagemann and Meyer, 1978). The ventriculograms obtained were of adequate quality for quantitative analysis by computerised videometry (Hagemann et al., 1976). Only the earliest systoles providing adequate opacification of the left ventricular cavity were analysed.

The Judkins technique was used for coronary arteriography. Biplane cineangiography of the left ventricle was performed in the $30^{\circ} \mathrm{RAO}$ position. $35 \mathrm{~mm}$ film was used, exposed at 50 frames/second. A bipolar electrode catheter ${ }^{3}$ inserted via a femoral vein was positioned against the wall of the right atrium. Effective pacing was obtained in all patients using pulses with an amplitude of $2.0 \mathrm{~V}$ and a duration of $1.0 \mathrm{~ms}$. There were no complications from catheterisation.

${ }^{1}$ Millar Instruments, Houston, Texas.

${ }^{2}$ Cordis Corporation, Miami, Florida.

'USCI, Glen Falls, New York.

\section{PROCEDURE}

All measurements were taken before coronary arteriography. After the catheters had been placed in position, atrial pacing was started at a rate of $80 / \mathrm{min}$ and continued for 3 minutes. Then left ventricular cineangiography was performed during atrial pacing. Left ventricular and aortic pressures were measured simultaneously, and the data stored on digital tape. After a recovery period of at least 20 minutes and when left ventricular systolic and end-diastolic pressures had returned to the control level the rate of pacing was increased to $120 / \mathrm{min}$ and continued for 3 minutes. When the new steady state was achieved cineangiography during atrial pacing was repeated, care being taken to ensure that the two ventriculograms were performed under the same conditions (amount of contrast medium, injection rate, $x$-ray factors, patient position, and position of tube and image intensifier).

\section{DATA PROCESSING AND CALCULATIONS}

Left ventricular and aortic pressures during cineangiography were calculated on line by a computer ${ }^{1}$ sampling at 400 times a second. This computer programme has previously been described in detail (Jensch et al., 1976). In addition, pressures, the electrocardiogram, and a frame exposure signal were recorded by a photographic recorder ${ }^{2}$ running at $100 \mathrm{~mm} / \mathrm{s}$. Ventricular volume was determined at $20 \mathrm{~ms}$ intervals by videometry after video camera scanning of the $35 \mathrm{~mm}$ films. Single plane contour tracings were done by light pen. Volumes were calculated according to Simpson's rule using the same computer as for pressure calculations (interactive dialogue system). Volumes obtained by videometry were calibrated by a metal sphere of known volume which had been filmed in the same position as the left ventricle. No regression equations for correction of volumes were used. Smoothing and differentiation of the volume curve was performed as described by Savitzky and Golay (1964). Left ventricular muscle mass in end-diastole was calculated according to the modified method of Rackley et al. (1964). Muscle mass was not assessed in patients with infarction. In the angiographic method, wall thickness is assumed to be uniform, which is not true after myocardial infarction, and thinning over the necrotic area causes muscle mass to be overestimated by an unknown amount.

Simultaneous pressure and volume data during angiography were collated by the computer to establish a basic pressure volume progression. Using a linear interpolation procedure for the

${ }^{1}$ General Automation, Inc., Anaheim, Cal.

'Electronics for Medicine, Inc., White Plains, N.Y. 


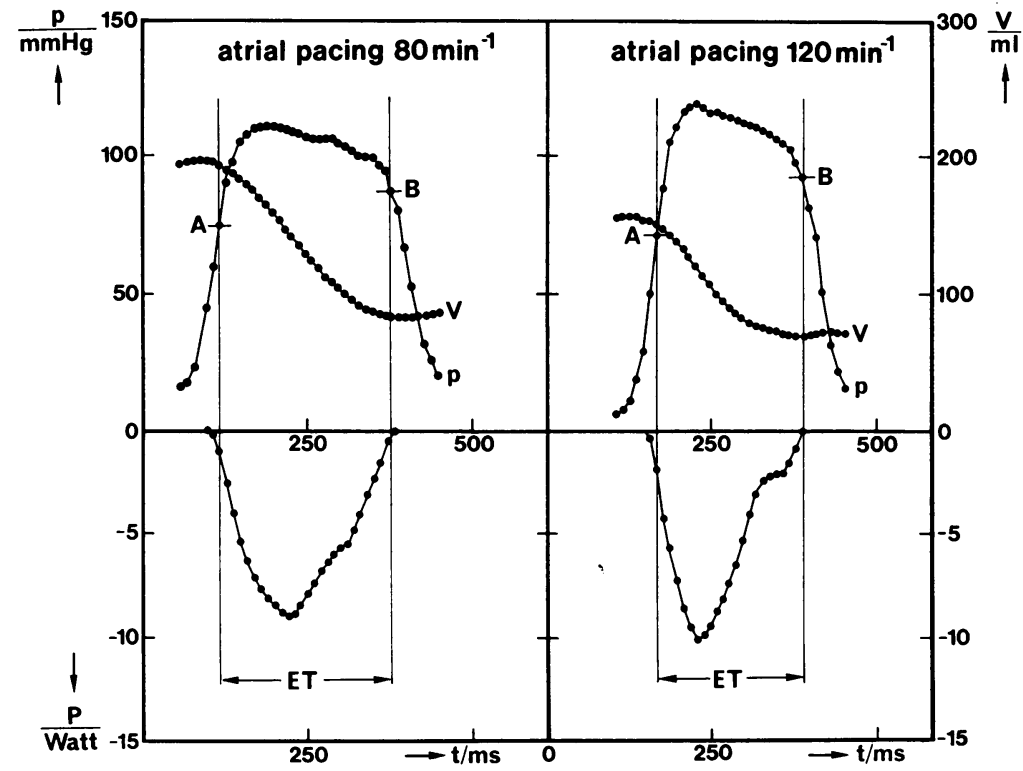

Fig. 1 Left ventricular pressure, volume, and ejection power in a normal subject (case 4) during atrial pacing at a rate of $80 / \mathrm{min}$ (left) and $120 / \mathrm{min}$ (right). Abbreviations: $p=$ pressure, $V=$ volume, $P=$ power, $E T=$ ejection time, $t=$ time, $A=$ aortic valve opening, $B=$ aortic valve closure. Power has been plotted on the negative y axis for mathematical reasons $(-P=p \times(-d V \mid d t))$. The negative sign has been neglected in the Tables and in the other Figures.

volume curve calculations of instantaneous left ventricular power were made automatically at 10 $\mathrm{ms}$ intervals. By plotting power against time a continuous power curve was obtained (Fig. 1). Left ventricular power during ejection was calculated according to the equation

$$
\mathrm{P}=\mathrm{p} \times \mathrm{dV} / \mathrm{dt}
$$

where $P=$ power, $p=$ instantaneous left ventricular pressure, and $\mathrm{dV} / \mathrm{dt}=$ instantaneous ejection blood flow. In SI units power is expressed in Watts. The conversion relation is

$$
\begin{array}{r}
\text { power }=1 \mathrm{mmHg} \times 1 \mathrm{ml} \times \mathrm{s}^{-1}= \\
1.333 \times 10^{-4} \text { Watt. }
\end{array}
$$

The ejection time for calculation of mean power was identified from the aortic pressure tracing. The ejection fraction (\%) was calculated as stroke volume/end-diastolic volume multiplied by 100 .

\section{STATISTICS}

Statistical analysis was performed using the paired and unpaired t test (Ostle, 1963; Brownlee, 1965). A significant difference was accepted at a level of $\alpha=5$ per cent $(P<0.05)$.

\section{Results}

The data are summarised in detail in Tables 1 and 2.

\section{END-DIASTOLIC VOLUME}

The end-diastolic volume in group I at heart rates of 80 and $120 / \mathrm{min}$ was lower than in group II as a whole $(P<0.05)$ and group IIb $(P<0.05)$. No significant difference however was found between groups I and IIa. When the rate was changed from 80 to $120 / \mathrm{min}$ end-diastolic volume decreased in groups I and IIa by 19 per cent and in group IIb. by 12 per cent.

\section{EJECTION FRACTION}

The ejection fraction at heart rates of 80 and $120 / \mathrm{min}$ in group II as a whole and group IIb was lower than in group I $(P<0.001)$. At $80 / \mathrm{min}$ group IIa showed no significant difference compared with group I, but at $120 /$ min the ejection fraction was significantly lower in group IIa $(P<0.02)$. When the rate was increased the ejection fraction decreased in groups IIa and IIb by 17 per cent whereas no change occurred in group I.

\section{PEAK AND MEAN EJECTION POWER}

No statistical difference in these indices was found between normal subjects and patients in groups II, $\mathrm{IIa}$, and IIb at heart rates of 80 and $120 / \mathrm{min}$. 
Table 1 Haemodynamic data on normal subjects (group I)

\begin{tabular}{|c|c|c|c|c|c|c|c|c|c|c|c|c|c|c|c|c|}
\hline \multirow[t]{2}{*}{$\begin{array}{l}\text { Case } \\
\text { no. }\end{array}$} & \multicolumn{2}{|c|}{$\begin{array}{l}\text { End-diastolic } \\
\text { (volume } \mathrm{ml} \text { ) }\end{array}$} & \multicolumn{2}{|c|}{$\begin{array}{l}\text { Ejection } \\
\text { fraction (\%) }\end{array}$} & \multicolumn{2}{|c|}{$\begin{array}{l}\text { LV muscle } \\
\text { mass }(g)\end{array}$} & \multicolumn{2}{|c|}{$\begin{array}{l}\text { Peak ejection } \\
\text { power }(m W)\end{array}$} & \multicolumn{2}{|c|}{$\begin{array}{l}\text { Mean ejection } \\
\text { power }(m W)\end{array}$} & \multicolumn{2}{|c|}{$\begin{array}{l}\text { Peak ejection } \\
\text { power } \\
\text { normalised by } \\
\text { end-diastolic } \\
\text { volume } \\
(\mathrm{mW} / \mathrm{ml})\end{array}$} & \multicolumn{2}{|c|}{$\begin{array}{l}\text { Mean ejection } \\
\text { power } \\
\text { normalised by } \\
\text { end-diastolic } \\
\text { volume } \\
(\mathrm{mW} / \mathrm{ml})\end{array}$} & \multicolumn{2}{|c|}{$\begin{array}{l}\text { Peak ejection } \\
\text { power } \\
\text { normalised by } \\
\text { muscle mass } \\
(\mathrm{mW} / \mathrm{g})\end{array}$} \\
\hline & $a$ & $b$ & $a$ & $b$ & $a$ & $b$ & $a$ & $b$ & $a$ & $b$ & $a$ & $b$ & $a$ & $b$ & $a$ & $b$ \\
\hline & 162 & 126 & 72 & 69 & 198 & - & 10929 & 9352 & 25920 & 5870 & $67 \cdot 5$ & & 32.5 & $39 \cdot 2$ & $55 \cdot 2$ & $47 \cdot 2$ \\
\hline 2 & 160 & 136 & 5 & 50 & 197 & - & 8812 & 7806 & 64225 & 43 & 55.0 & 81 & $23 \cdot 2$ & 32.0 & 44 & $39 \cdot 6$ \\
\hline 3 & 172 & 153 & 65 & 48 & 18 & - & & 7951 & 147 & & & & & & & 42.0 \\
\hline 4 & 198 & 156 & 58 & 57 & 170 & - & 9066 & $\begin{array}{lll}6 & 10233\end{array}$ & $\begin{array}{ll}35888 \\
\end{array}$ & 5404 & $45 \cdot 8$ & $65 \cdot 6$ & 25.9 & 30.5 & $53 \cdot 3$ & $60 \cdot 2$ \\
\hline 5 & 124 & 92 & 64 & 67 & 132 & - & 5537 & & $4 \quad 4058$ & & $74 \cdot 3$ & 64 & & & 41 & 41.7 \\
\hline 6 & 172 & 134 & 56 & 58 & 185 & - & 6772 & 9627 & $\begin{array}{l}7 \\
7279\end{array}$ & 5192 & $39 \cdot 3$ & $72 \cdot 0$ & $30 \cdot 3$ & 38 & 36 & 52.0 \\
\hline Mean & 164 & 133 & 62 & 58 & 179 & - & 7961 & 8412 & 25017 & 4817 & $53 \cdot 4$ & $68 \cdot 2$ & $27 \cdot 8$ & $33 \cdot 1$ & 44.5 & $47 \cdot 1$ \\
\hline$\pm \mathrm{SD}$ & \pm 24 & \pm 23 & \pm 7 & \pm 9 & \pm 25 & - & \pm 1988 & \pm 1715 & \pm 809 & \pm 833 & \pm 14.9 & \pm 9.9 & \pm 3.4 & \pm 5.9 & \pm 8.3 & $\pm 7 \cdot 8$ \\
\hline & & $<0.001$ & & NS & & - & & & & NS & & $<0.01$ & & $<0.05$ & & NS \\
\hline
\end{tabular}

$\mathrm{a}, \mathrm{b}=$ atrial pacing 80 and $120 / \mathrm{min}$, respectively.

The increase in heart rate did not significantly change peak and mean ejection power in group I and group IIb but in group IIa they decreased significantly by 25 and 18 per cent, respectively (both $\mathrm{P}<0.001$ ).
PEAK AND MEAN EJECTION POWER NORMALISED BY END-DIASTOLIC VOLUME At $80 / \mathrm{min}$ there was no difference in peak power normalised by end-diastolic volume between normal subjects and those in groups II, IIa, and IIb.

Table 2 Haemodynamic data on patients with coronary artery disease (group II, IIa, IIb)

\begin{tabular}{|c|c|c|c|c|c|c|c|c|c|c|c|c|c|c|c|c|}
\hline \multirow[t]{2}{*}{$\begin{array}{l}\text { Case } \\
\text { no. }\end{array}$} & \multicolumn{2}{|c|}{$\begin{array}{l}\text { End-diastolic } \\
\text { volume }(\mathrm{ml})\end{array}$} & \multicolumn{2}{|c|}{$\begin{array}{l}\text { Ejection } \\
\text { fraction }(\%)\end{array}$} & \multicolumn{2}{|c|}{$\begin{array}{l}\text { LV muscle } \\
\operatorname{mass}(g)\end{array}$} & \multicolumn{2}{|c|}{$\begin{array}{l}\text { Peak ejection } \\
\text { power }(m W)\end{array}$} & \multicolumn{2}{|c|}{$\begin{array}{l}\text { Mean ejection } \\
\text { power }(m W)\end{array}$} & \multicolumn{2}{|c|}{$\begin{array}{l}\text { Peak ejection } \\
\text { power } \\
\text { normalised by } \\
\text { end-diastolic } \\
\text { volume } \\
(\mathrm{mW} / \mathrm{ml})\end{array}$} & \multicolumn{2}{|c|}{$\begin{array}{l}\text { Mean ejection } \\
\text { power } \\
\text { normalised by } \\
\text { end-diastolic } \\
\text { volume } \\
(\mathrm{mW} / \mathrm{ml})\end{array}$} & \multicolumn{2}{|c|}{$\begin{array}{l}\text { Peak ejection } \\
\text { power } \\
\text { normalised by } \\
\text { muscle mass } \\
(\mathrm{mW} / \mathrm{g})\end{array}$} \\
\hline & $a$ & $b$ & $a$ & $b$ & $a$ & $b$ & $a$ & $b$ & $a$ & $b$ & $a$ & $b$ & $a$ & $b$ & $a$ & $b$ \\
\hline \multicolumn{17}{|c|}{ Group IIa (no myocardial infarction) } \\
\hline 8 & 194 & 136 & 56 & 48 & 220 & 一 & 12533 & 9749 & 5303 & 3954 & $64 \cdot 6$ & $71 \cdot 1$ & $25 \cdot 8$ & $23 \cdot 6$ & 55.9 & $44 \cdot 3$ \\
\hline 9 & 217 & 205 & 47 & 39 & 256 & 一 & 9866 & 8663 & 6484 & 5204 & $45 \cdot 5$ & $42 \cdot 3$ & $24 \cdot 6$ & 20.5 & $38 \cdot 5$ & $33 \cdot 8$ \\
\hline 10 & 208 & 124 & 45 & 46 & 252 & - & 9699 & 5814 & 5821 & 4391 & $46 \cdot 6$ & $46 \cdot 8$ & $23 \cdot 4$ & $30 \cdot 0$ & $38 \cdot 4$ & 23.0 \\
\hline 11 & 183 & 160 & 48 & 38 & 165 & - & 7376 & 5704 & 4266 & 3501 & $40 \cdot 3$ & $35 \cdot 7$ & $18 \cdot 6$ & $17 \cdot 0$ & $46 \cdot 5$ & $34 \cdot 5$ \\
\hline 12 & 153 & 130 & 70 & 52 & 213 & 一 & 9081 & 6297 & 5076 & 4440 & $59 \cdot 4$ & $48 \cdot 4$ & $33 \cdot 2$ & $34 \cdot 2$ & $42 \cdot 6$ & $29 \cdot 5$ \\
\hline Mean & 187 & 152 & 54 & 45 & 216 & 一 & 9923 & 7424 & 5268 & 4344 & 53.7 & $49 \cdot 7$ & $25 \cdot 0$ & $25 \cdot 2$ & $46 \cdot 7$ & $34 \cdot 7$ \\
\hline \pm SD & \pm 24 & $\begin{array}{l} \pm 30 \\
<0.05\end{array}$ & \pm 9 & $\begin{array}{l} \pm 6 \\
<0.05\end{array}$ & \pm 35 & - & \pm 1743 & $\begin{array}{l} \pm 1706 \\
<0.001\end{array}$ & \pm 800 & $\begin{array}{l} \pm 577 \\
<0.001\end{array}$ & \pm 11 & $\begin{array}{r} \pm 12 \\
\text { NS }\end{array}$ & $\pm 4 \cdot 7$ & $\begin{array}{l} \pm 6 \cdot 3 \\
\text { NS }\end{array}$ & \pm 8.6 & $\begin{array}{l} \pm 8.2 \\
<0.001\end{array}$ \\
\hline
\end{tabular}

Group IIb (myocardial infarction)

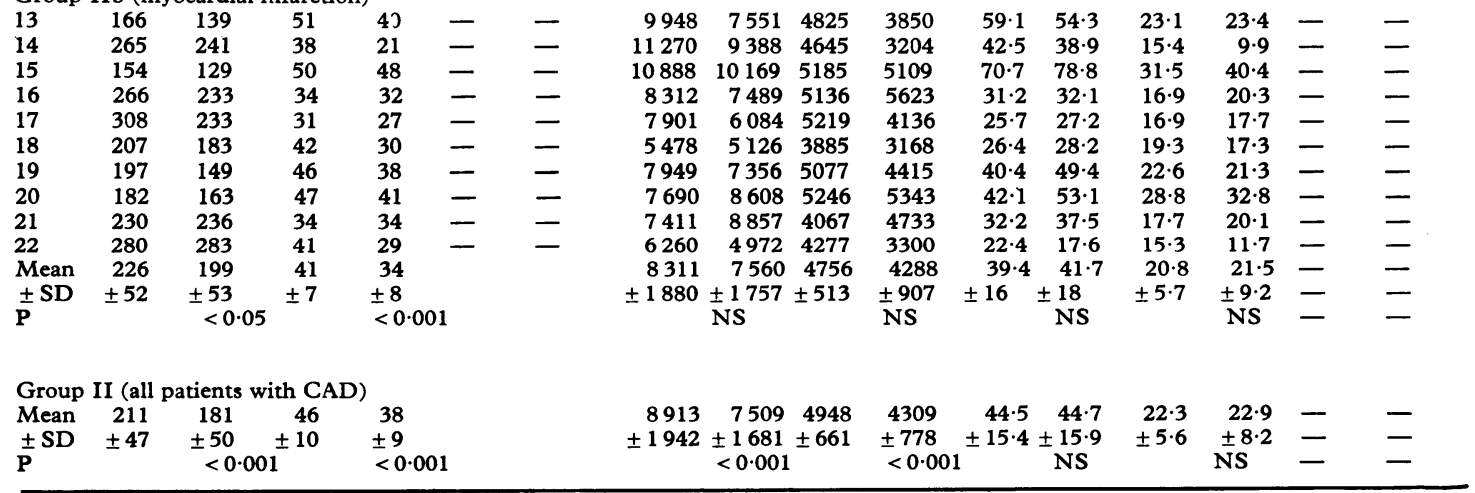

$a, b=$ atrial pacing 80 and $120 / \mathrm{min}$, respectively. 


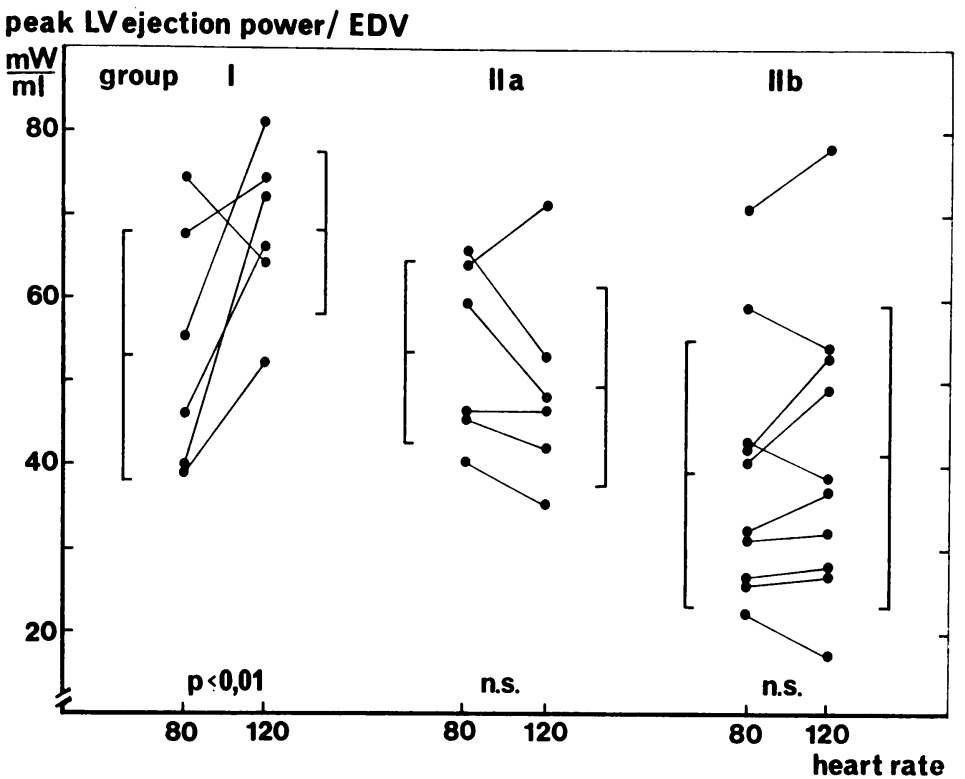

Fig. 2 Peak left ventricular ejection power normalised by end-diastolic volume. Normals $(I)$ and patients with coronary artery disease without myocardial infarction (IIa) and after myocardial infarction (IIb). Atrial pacing 80 and $120 /$ min.

At $120 / \mathrm{min}$, however, it rose 28 per cent in group I but remained unchanged in both coronary groupsa significant difference (group II as a whole, $P<0.01$, group IIa, $P<0.02$, and group IIb, $P<0.01$ ) (Fig. 2). Mean power normalised by end-diastolic volume was significantly higher at $80 / \mathrm{min}$ in normal subjects when compared with group IIb $(P<0.02)$ and group II as a whole $(P<0.05)$ but not with group IIa. At $120 / \mathrm{min}$ the difference achieved significance for all coronary groups (IIa, $\mathrm{P}<0.05$, IIb, $\mathrm{P}<0.02$, and group II as a whole, $P<0.02$ ), the increase in rate producing a 19 per cent rise in normal subjects but no change in the coronary patients (Fig. 3).

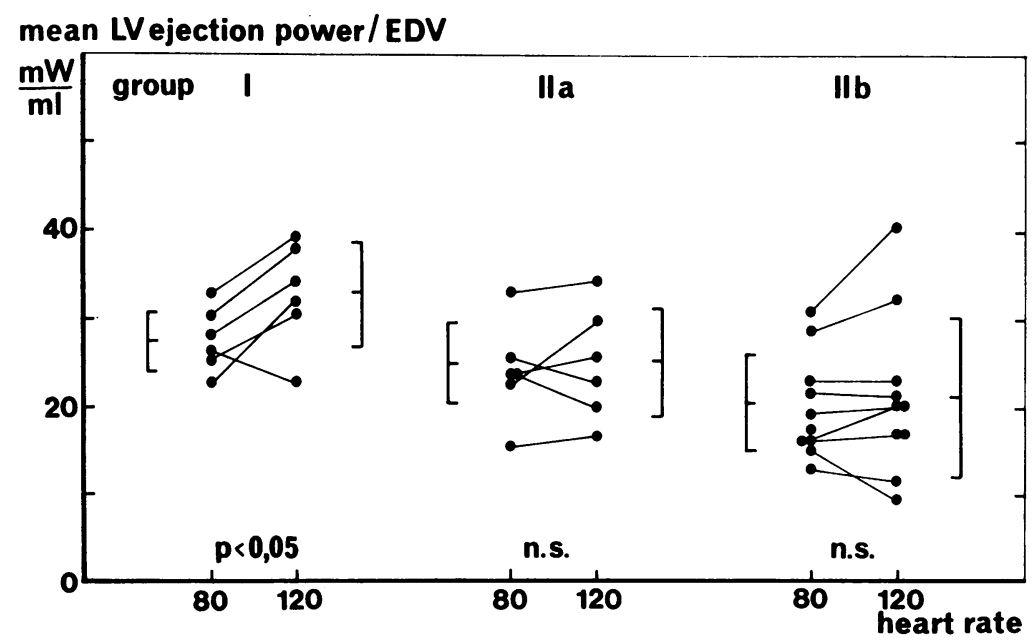

Fig. 3 Mean left ventricular ejection power normalised by end-diastolic volume. Atrial pacing 80 and 120/min. See legend Fig. 2. 


\section{EJECTION TIME}

Ejection time as determined from the aortic pressure tracing at heart rates of 80 and $120 / \mathrm{min}$ was $273 \pm$ $25 \mathrm{~ms}$ and $232 \pm \mathrm{ms}$ respectively in group I, $283 \pm 20 \mathrm{~ms}$ and $236 \pm 12 \mathrm{~ms}$ respectively in group IIa, $280 \pm 27 \mathrm{~ms}$ and $227 \pm 28 \mathrm{~ms}$ respectively in group IIb, and $281 \pm 24 \mathrm{~ms}$ and $230 \pm$ $23 \mathrm{~ms}$ respectively in group II as a whole. The decrease in ejection time was significant in all groups $(P<0.001)$ but there was no statistically significant difference between the groups themselves.

\section{LEFT VENTRICULAR MUSCLE MASS}

End-diastolic muscle mass in normal subjects at a heart rate of $80 / \mathrm{min}$ was $179 \pm 25 \mathrm{~g}$. Muscle mass in group IIa was significantly higher than in normal subjects $(216 \pm 35, P<0.05)$.

\section{PEAK EJECTION POWER NORMALISED BY}

\section{MUSCLE MASS}

Peak ejection power normalised by muscle mass at a heart rate of $80 / \mathrm{min}$ was $44.5 \pm 8.3 \mathrm{~mW} / \mathrm{g}$ in normal subjects and $46.7 \pm 8.6 \mathrm{~mW} / \mathrm{g}$ in patients in group IIa (NS). In normal subjects it remained essentially unchanged when the rate was altered to $120 / \mathrm{min}$. In group IIa it decreased by 26 per cent to $34.7 \pm 8.2 \mathrm{~mW} / \mathrm{g}(\mathrm{P}<0.001)$ (Fig. 4). The difference between normal subjects and patients in

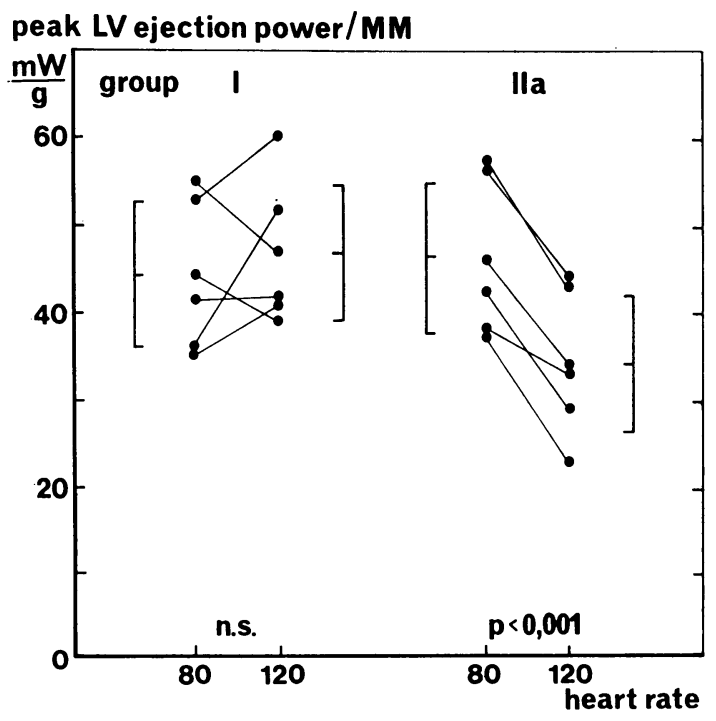

Fig. 4 Peak left ventricular ejection power normalised by left ventricular muscle mass. Normal subjects $(I)$ and patients with coronary artery disease without myocardial infarction (IIa). Atrial pacing 80 and 120/min. group IIa at a heart rate of $120 / \mathrm{min}$ was significant $(P<0.05)$.

\section{Discussion}

The left ventricle works as, and is broadly similar to, a mechanical hydraulic pump. In mechanics, pumps are characterised by their peak and mean hydraulic power for a given cycle length and the data needed for the determination of pump power are pressure, volume, and time. However, since ventricular power changes dynamically throughout the cardiac cycle, these indices have to be analysed simultaneously in adequate detail for its study. Furthermore, it is essential to relate ventricular power to a constant cycle length, that is to heart rate.

Bearing these points in mind this investigation was designed to determine the levels of ventricular power during ejection at rest and under stress in normals and in patients with coronary heart disease. Chronic ischaemia of the myocardium as a result of coronary artery stenosis leads to impairment of ventricular pump function, and while this has been shown for other ejection phase indices of ventricular performance (ejection fraction, stroke volume, cardiac output, stroke work, etc. (Sonnenblick and Strobeck, 1977) these do not allow for time, which is an important variable in myocardial dynamics.

Studies of ventricular power in animals and in man have been reported by Chapman et al. (1959), Bunnell et al. (1962), Hernandez et al. (1964), Greenfield et al. (1968), and Snell and Luchsinger (1965). Russel et al. (1971) and Steinand Sabbah (1976 $a, b)$ investigated left ventricular ejection power in various cardiac abnormalities at rest, but their data can only partly be compared with our own; in particular the heart rate was not kept constant. In our patients, however, this was achieved by the use of atrial pacing, both for basal measurements (at $80 / \mathrm{min}$ ) and for stress testing (at $120 / \mathrm{min}$ ). It has been shown previously that rapid atrial pacing is an acceptable method of stressing the heart (Forrester et al., 1971) and in our opinion it is superior to others, such as treadmill testing, pharmacological intervention, or volume loading, for it interferes very little with the systemic circulation in terms of peripheral resistance, mean arterial pressure, and intravascular volume. In addition, it gives results of high reproducibility, which aids the direct comparison of different subjects.

Our findings showed that measured peak left ventricular ejection power under basal conditions was essentially the same in both normal subjects and patients with coronary artery disease, with 
and without myocardial infarction, though the latter tended to have higher values. This may be explained by the myocardial hypertrophy (increased muscle mass) which was found in this group. However, under stress, peak power fell appreciably in both coronary groups (while in normal subjects it tended to rise) and this fall was statistically significant in the patients without infarction, even though there was no statistical difference in peak left ventricular power at either heart rate between the groups. Similar results were obtained for measured mean left ventricular power and it seemed necessary, therefore, to 'normalise' power by relating it to indices which represent the dimension of the ventricle and the mass of its wall. End-diastolic volume, as a measure of muscle fibre length before contraction, was higher in the patients with coronary artery disease than in the normal subjects. This finding is well known (Dwyer, 1970); chronic myocardial ischaemia induces ventricular hypertrophy and dilatation. At the basal heart rate, peak left ventricular power normalised by end-diastolic volume was in the same range in all the 3 groups, though patients with infarction tended to have lower values. When the heart rate was increased, this rose significantly in normal subjects but remained unchanged in both groups of patients with coronary artery disease. Mean left ventricular power normalised by end-diastolic volume, however, was significantly lower at both heart rates in patients with infarction than in normal subjects, and the rate increase led to a rise in this index in normal subjects but not in either coronary group. These results indicate that whereas, normally, ventricular power rises with heart rate, in coronary disease the limited oxygen supply prevents this.

Left ventricular muscle mass was determined in normal subjects and the group without infarction only; it was significantly higher in the latter. Peak power values normalised by muscle mass at rest were in the same range in both, but under stress decreased significantly in the coronary group alone. Similar results were obtained for mean power/g muscle mass. Thus, myocardial hypertrophy in chronic ischaemic heart disease without infarction compensates only in part for loss of pump function. Under moderate stress (here, tachycardia at $120 / \mathrm{min}$ ) the energy output per unit of muscle mass not only cannot be maintained but indeed falls to critical levels, indicating impending heart failure. This study, then, proves left ventricular power to be of value in delineating myocardial performance at rest and under stress. Further work is needed to determine the influence of the extent and localisation of coronary artery lesions, of arrhythmias, and of drugs, on this measurement.

\section{References}

Brownlee, K. A. (1965). Statistical Theory and Methodology in Science and Engineering. 2nd ed. John Wiley, New York, Chichester, Toronto, and Sydney.

Brutsaert, D. L., and Sonnenblick, E. H. (1973). Cardiac muscle mechanics in the evaluation of myocardial contractility and pump function: problems, concepts and directions. Progress in Cardiovascular Diseases, 16, 337-361.

Bunnell, I. L., Grant, C., and Greene, D. G. (1962). The measurement of left ventricular power and wall tension in man (abstract). Physiologist, 5, 115.

Chapman, C. B., Baker, P., and Mitchel!, J. H. (1959). Left ventricular function at rest and during exercise. fournal of Clinical Investigation, 38, 1202-1213.

Dwyer, E. M., Jr. (1970). Left ventricular pressure-volume alterations and regional disorders of contraction during myocardial ischemia induced by atrial pacing. Circulation, 42, 1111-1122.

Forrester, J. S., Helfant, R. H., Pasternac, A., Amsterdam, E. A., Most, A. S., Kemp, H. G., and Gorlin, R. (1971). Atrial pacing in coronary heart disease. American fournal of Cardiology, 27, 237-243.

Greenfield, J. C., Jr., Harley, A., Thompson, H. K., and Wallace, A. G. (1968). Pressure-flow studies in man during atrial fibrillation. Fournal of Clinical Investigation, 47, 2411-2421.

Hagemann, K., Krebs, W., Meyer, J., Platte, G., Effert, S., and Ameling, W. (1976). Evaluation of cardiac mechanics by videometry and on line pressure analysis. In 7 th European Congress of Cardiology, Amsterdam (abstract).

Hagemann, K., and Meyer, J. (1978). Angiography of the left ventricle using right atrial injection. Klinische Wochenschrift, 56, 351-354.

Hernandez, R. R., Greenfield, J. C., Jr., and McCall, B. W. (1964). Pressure-flow studies in hypertrophic subaortic stenosis. Fournal of Clinical Investigation, 43, 401-407.

Jensch, P., Meyer, J., Mattar, E., Ameling, W., and Effert, S. (1976). Ein Prozessrechnersystem für Herzkatheterlabor und Hämodynamikmeßplätze. Zeitschrift für Kardiologie, 65, 850-881.

Ostle, B. (1963). Statistics in Research. Iowa State University Press, Ames, Iowa.

Rackley, C. E., Dodge, H. T., Coble, Y. D., Jr., and Hay, R. E. (1964). A method for determining left ventricular mass in man. Circulation, 29, 666-671.

Russel, R. O., Jr., McGavock Porter, C., Frimer, M., and Dodge, H. T. (1971). Left ventricular power in man. American Heart fournal, 81, 799-808.

Savitzky, A., and Golay, M. E. (1964). Smoothing and differentiation of data by simplified least squares procedures. Analytical Chemistry, 36, 1627-1639.

Snell, R. E., and Luchsinger, P. C. (1965). Determination of the external work and power of the left ventricle in intact man. American Heart fournal, 69, 529-537.

Sonnenblick, E. H., and Strobeck, J. E. (1977). Derived indexes of ventricular and myocardial function. New England Fournal of Medicine, 296, 978-982.

Stein, P. D., and Sabbah, H. N. (1976a). Rate of change of ventricular power: an indicator of ventricular performance during ejection. American Heart fournal, 91, 219-227.

Stein, P. D., and Sabbah, H. S. (1976b). Ventricular performance measured during ejection: studies in patients of the rate of change of ventricular power. American Heart fournal, 91, 599-606.

Requests for reprints to Dr K. Hagemann, Department of Internal Medicine I, Goethestrasse 27/29, 5100 Aachen, Federal Republic of Germany. 